\title{
A Slice of a Baking Cake: Language and Literacy Education Issues in Schooling Systems
}

\author{
Khadijeh Aghaei \\ $\mathrm{PhD}$ in ELT \\ English Language Teaching \& Literature Department \\ Humanities Faculty, Gonbad Kavous University, Gonbad Kavous, Iran \\ E-mail: aghaei.khadijeh@gmail.com or aghaee@gonbad.ac.ir
}

Received: September 1, 2016 Accepted: September 14, 2016 Published: September 22, 2016

doi:10.5296/gjes.v2i2.10065 URL: http://dx.doi.org/10.5296/gjes.v2i2.10065

\begin{abstract}
The concept of literacy remained as a buzzword especially in the new era with its all turbulence. Its disciplines of thought can shape groundbreaking perspectives, refreshing the way we approach problems and generating paths of study associated with 21st century careers, relationships, lifestyles and citizens. Although new perspectives to literacy are being emerged, literacy in many educational settings in developing contexts, here Iran is still defined in its old fashioned concept i.e. acquiring a set of neutral skills. Hence, understanding new trends to literacy studies can be achieved through a rather comprehensive review from its starting point to its status quo. This paper tends to crystallize the paradigms occurred in literacy development and shed more light on its new horizons for those who are eager on rethinking knowledge epistemology and ontology for future directions in various educational setting, specially schooling systems.
\end{abstract}

Keywords: Literacy Studies, New Literacy Studies, Literacy Development, Schooling Settings, ELT 


\section{Introduction}

The concept of literacy remained as a buzzword especially in the new era with its all turbulence. Its disciplines of thought can shape groundbreaking perspectives, refreshing the way we approach problems and generating paths of study associated with 21 st century careers, relationships, lifestyles and citizens. Although literacy became a loaded concept which its different scenarios are being written, the concepts of literacy in many developing educational contexts are restricted to specific set of neutral skills at individual level. These concepts are indeed detached from society and its embedded discursivities. Taken from a chronological review, this study tends to provide an answer for a set of questions on what counted literacy in the past and today. How can these meanings contribute to its development? Answer to these questions is an issue which necessitates more attention to the field for different educational stakeholders in different contexts either developing or developed as a turning back to literacy meaning.

\section{The Current Landscape of Literacy/Literacies}

Literacy is a controversial concept that has been defined by many as theoretical insights. It has been documented to be both dynamic and complex, continuing to be read in a multiplicity of manner (Fransman, 2006). The focus of these differing views, evolving from literacy as a set of skills (i.e., reading and writing) to literacy as a text in its broadest sense (oral, visual, written, digital, etc.), have ranged from changes in individuals to making a difference in broader socio-economic and political contexts (Cadiero-Kaplan, 2004; Wray, 2001). Literacy programs and policies, too, are inevitably selections from the range of approaches informed by these underlying theories. Based on the current landscape of literacy, it is possible to distinguish between two major and general orientations towards literacy development in programs and policies: functional literacy development and progressive literacy development.

\subsection{Functional Literacy Development}

Literacy as a set of autonomous skills, specifically the skills of reading and writing, was perhaps the most agreed upon understanding of what makes literacy (Cadiero-Kaplan, 2004; Fransman, 2006). From this perspective, which is mainly informed by research in the field of cognitive sciences, literacy skills are regarded as independent of the acquired context and the background of the person who acquires them. In addition, this understanding has "a toolbox approach" to literacy (Wray, 2001, p. 201); that is, learning of literacy skills and sub-skills will ultimately produce writing and reading. It is worthwhile noting that the focus on reading and writing, as the two main literacy skills, was based on the assumption that writing is the speech transcription and as such superior to it (Kress, 2003).

As very well noted by Street (2005), such an assumption also maintains that the purpose of literacy enterprise should be providing the context for transition from oral to literate cultures as the foundation for economic growth and development. Recently, however, there has been a shift in viewing literacy to embrace other aspects ranging from the oral linguistics and non-linguistic skills (including listening and speaking) as well as visual, media, and information skills. Curricula informed by a functional orientation to literacy development are 
those which teach students the skills necessary in order to perform successfully in different societal contexts such as school (Cadiero-Kaplan, 2004). The importance of such skills, which are regarded as universal and applicable in every context for curriculum development, lies in the fact that they are able to produce individuals who are productive citizens and members of the workforce. "A person who is functionally literate is generally considered an individual who has the ability to read and write to complete job applications and other common forms, [as well as] read and write checks, etc." (Cadieor-Kaplan, 2004, p. 5). To this end, the ultimate goal of such curricula and their related instructional practices, according to Myers (1996), is to provide learners with the opportunity to comprehend text by decoding words and understanding vocabulary and grammar. Functional literacy curricula have been extensively adopted by literacy programs in education (e.g., L2 literacy programs) due to their emphasis on immediate literacy outcomes and learner performance in education.

This orientation towards literacy development, however, has been widely challenged by those who believe that a commonplace focus on skills development takes for granted the critical social practices, rooted in conceptions of identity, knowledge, and power. The critics of functional literacy curricula argue that traditional approaches to skills development fail to address important issues such as racial inequalities, political marginalization, and historical Eurocentric and cultural biases (see, for example, Fecho, 2000; Vavrus, 2002).

In addition, attaining literacy in the sense of phonological and/or orthographic decoding, does not automatically lead to learners' critical engagement with text and as such fails to facilitate an equitable learning environment (Graff, 2003).

\subsection{Progressive Literacy Development in Education}

As a response to the inadequacies of functional literacy programs in some educational settings, a new framework in education has been emerged, which emphasizes the production of literate learners who can participate in relevant social and cultural contexts and are able to engage flexibly in them (Banks, 2004; Barton, Hamilton, \& Ivanic, 1999; Fecho, 2000; Gee 1999; Street, 2003). Literacy within this view has undergone a shift from being considered a mere acquisition of independent skills to being 'situated' and 'social', with a focus on everyday meanings and uses in specific cultural contexts (Street, 2003; 2004). Curricula informed by the notion of situated literacy are those that "encourage the inclusion of student voice, culture and a variety of literature and discourses as the part of the curriculum" (Cadiero-Kaplan, 2004, p. 10). Within this perspective, social discourse is considered as a part of learning.

In addition, learners are provided with the opportunity to make "their own decisions about what to read write and learn" (Weaver, 1998, p. 7). Progressive curricula, as such, unlike functional literacy which saw literacy as decontextualized and individual level, value learners as knowing subjects and provide a space for them to (re)construct meaning in a socially and situated manner. Franceman (2006, p. 240) cites a passage from Rodgers that well reflects learners' decisions at the core of curriculum development and pedagogical practices: "Women in a literacy program in Rajasthan, India rejected their traditional and irrelevant textbooks in favor of cinema adverts and movie clippings. Since they already knew many of the names 
and words and were interested in the topic they learnt quickly and gained much confidence". A progressive orientation to literacy development calls for a pedagogy based on student inquiry that crosses cultures, empowers learners, and results in social betterment (Fecho, 2000).

\section{Critical Turns to Literacy Studies}

Although, progressive literacy have developed the notion of literacy as situated, contextualized, more critical approaches to literacy have problematized literacy with its consequences for social and personal development (Street, 1995). These approaches which were known as the New Literacy Studies (NLS), have tried to provide a replacement of the autonomous model of literacy with an ideological model, where situated approaches to literacy are focused (Collins \& Blott, 2003, Street, 1995). More specifically, NLS studies have focused on power relationships that encompass literacy practices, "to find new ways of linking the linguistic, the cognitive and the social; and to confront the meanings of schooling and literacy in circumstances of worldwide economic downturn" (Collins, 1995, p. 80).

The paradigm shift, as a result of more recent understandings of critical social justice (Masny $\&$ Cole, 2008), has led the concept of literacy to undergo further transformation to include the notion of critical engagement with processes of sense-making which, according to Masny (2005) involve reading the word, the world and the self. Heavily informed by the works of New London Group, the concept of Multiliteracies Theory (Cope \& Kalantzis, 2003) hold that literacies are social constructs and are of multi-modal nature (Cope \& Kalantzis, 2003). However, language and literacies concern not only the cultural and social aspects of meaning making but also the subtle sociopolitical interrelationships involved in any sense-making event using different modes. Multiliteracies theory, therefore, envisions literacy curricula that encourage production of literacies through immersion with different settings (e.g., school, home and community), "shaped by social, political, and historical contexts within a society" (Masny \& Cole, 2008, p. 3). In addition, literacies, as understood by Multiliteracies theory, are interactive sense-making events whose unceasing consequences are not limited only to social betterment (as in progressive language and literacy development), or any other social agenda for that matter.

The conception of literacies as critical sense-making processes, according to Masny (2005), highlights the notion of text as a central category, which takes on multiple meanings transferred by words, attitudes, gestures, and ways of writing, speaking and valuing. In addition, in Multiliteracies theory, texts are taken up as oral, visual, written, and tactile, which "interweave with religion, gender, race, ideology, and power" (Masny \& Cole, 2008, p. 2). The details of Multiliteracies theory (New London Group) are discussed as follows.

The concept of multiliteracies originated in an article in 1996 produced after discussions by a panel of well-known literacy scholars in New London, New Hampshire, USA. The main aim of this panel discussion was to explore how language and literacy education should react to the ever-increasing shifts made by cultural diversities of the new era (Cope \& Kalantzis 2008, Lankshear \& Knobel, 2011). Their discussions started with the desirable cultural consequences of being literate and the needed pedagogies for achieving them. The outcome 
of their discussion (New London Group, 1996), as Anstey and Bull (2006) and also Lankshear and Knobel (2011) pointed out, was that the goal of educational attempts should be on making learners ready for social, cultural futures in which they dynamically participate.

In this discussion, the term "Multiliteracies" refers to the cultural ways in which people adapt to the changing nature of communication nowadays and to identify what the learners have in order to achieve success in their own lives (Stevens, 2006; Lankshear \& Knobel, 2011). In other words, learners should be designers of their cultural futures. Multiliteracies as a specific pedagogic framework can be useful in an EFL classroom because it allows for conceptualising the prospect of language literacy teaching in the complex context of the world. To accommodate the cultural shifts in our complex world, new practices are needed for achieving a citizenship in this local-global connectedness era which is embedded with multiple literacies (Cope \& Kalantzis, 2003; Street \& Lefstein, 2007).

The concept of "multiliteracies" as a more wide-ranging term acknowledges that multiple words are interwoven in multiple cultural worlds (Lotherington, 2007, Leung \& Street, 2012). This idea has been welcomed by a large number of scholars who challenge the notion of a singular, monolithic literacy limited to a monocultural, and standard view to language (Gee, 1996; Pahl \& Rowsell, 2005, Leung \& Street, 2012; Brice Heath \& Street, 2008; Ellis, Street, $\&$ Fox, 2007). In fact, the New London Group (2000) tries to expand the notion of language literacy and literacy education to embrace the negotiation of a multiplicity of literacies. The multiplicity introduced by them includes two principal aspects. Firstly, they want to "extend the idea and scope of language and literacy pedagogy to account for the context of our culturally and increasingly globalised societies." Secondly, they argue that "[Language] and literacy pedagogy must now account for the burgeoning variety of text forms" (New London Group, ibid, p. 9) in the new era. Anstey and Bull (2006, p. 19) also indicate that, multiliteracies is a "concept that has evolved in response to concerns about how language and literacy teaching can equip learners for the changing world in which they live". With that goal in mind, teachers need to help learners develop the capacity to produce, read, and interpret face to face, print, and technological texts in the multicultural complex world they are living in. Likewise, learners need to "acquire practices they need for different domains, i.e. leisure, work active citizenship and participation in cultural and social community activities, and personal growth".

According to Anstey and Bull (Ibid ), this perspective gives rise to the view that "a literate person: (1) is flexible: strategically responsive to changing literacies and; (2) can maintain mastery: knowledgeable enough to be capable of reformulating existing knowledge and learn new literate practices; (3) has a repertoire of practices: enjoying a wide range of different knowledge, strategies and skills to apply as appropriate; (4) can make use of various kinds of texts including (a) traditional texts like print and paper textbooks, magazines, newspapers, (b) face-to-face or live texts like classroom interactions between teacher and learners; and (c) digital and electronic texts. In general, the growing body of works related to the multiliteracies view of language and literacy (see for example Durrant \& Green 2000; Freebody \& Luke, 2003; Cope \& Kalantzis, 2009; Lankshear \& Knobel, 2011) can develop understandings from texts as follows: 


\section{Macrothink}

- A text can be in different forms - paper, electronic, or live.

- A text may be consisting of one or more semiotic systems.

- Texts are meaningfully constructed.

- Meanings are dynamically constructed.

- A text may be of numerous promising meanings.

- Texts can be linear, nonlinear and also interactive.

In summary, the New London Group (2000, p. 10) intended to address both "the defining of literacy and the implications of the practices needed for the many varied contexts of the $21 \mathrm{st}$ century, including the multiplicity of communications channels and increasing cultural diversity in the world today". Learners in our complex world are users of various texts and need to take advantage of the changing literacy practices of work, power, and community which help them with the necessary critical engagement required to design their cultural futures (Stevens, 2006). Hence, as Anstey and Bull (ibid, p. 24) and the New London Group (2000) and later Lankshear and Knobel (2011) explain, it can be concluded that the multiliteracies view focuses on how literacy practices in educational settings are being influenced by local and global cultural changes. In fact, a multiliterate person is expected to focus on: (1) concepts of various kinds of texts in the $21^{\text {st }}$ century, and (2) the influence of increasing cultural diversities on literacy, literate practices, and critical literacy. In other words, a multiliterate person as shown in Figure 1 should be flexible and strategic; he or she should comprehend and apply literacy and literate practices (1) with a wide range of texts, (2) in a culturally responsive manner, (3) in a socially, culturally diverse world; and (4) fully take part in life as an informed and active citizen.

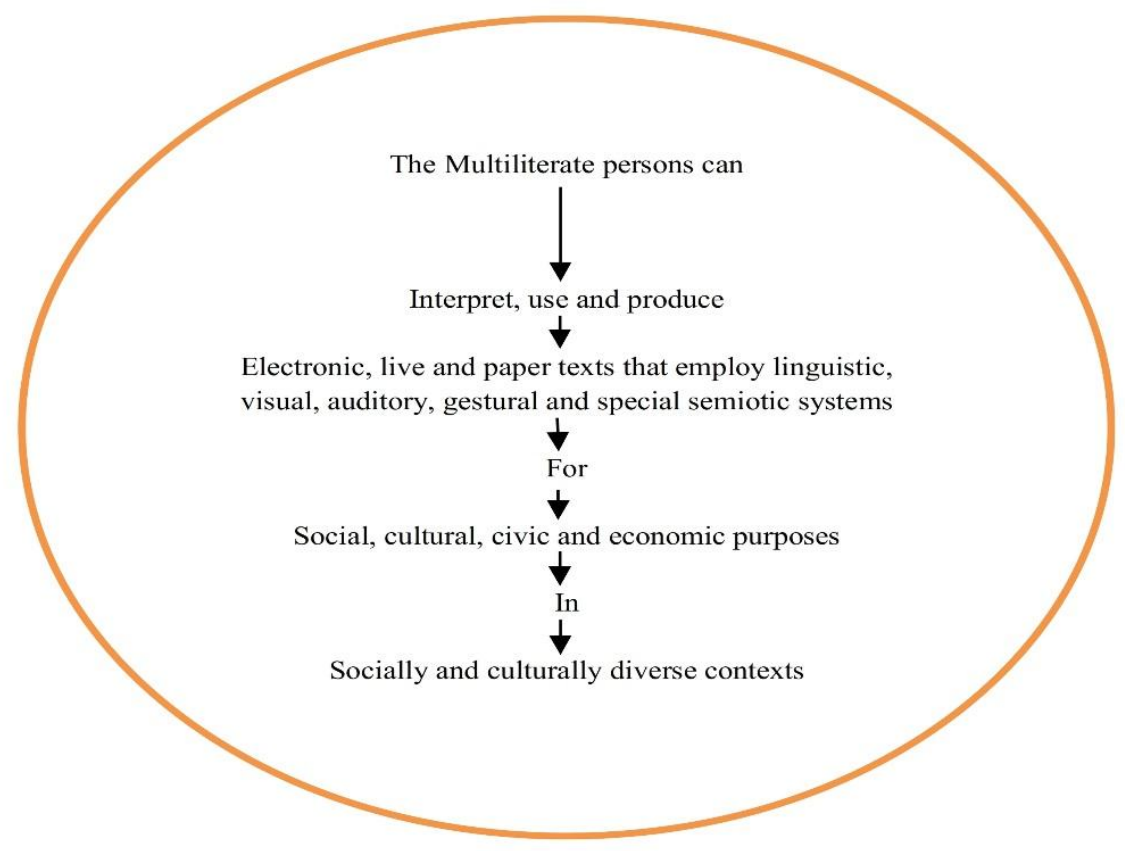

Figure 1. Characteristics of a multiliterate person (Anstey \& Bull, 2006, p. 41) 


\section{Al Macrothink}

Global Journal of Educational Studies

ISSN 2377-3936

2016, Vol. 2, No. 2

\section{Concluding Remarks}

Although different scopes of literacy garnered many attentions in literature, its new critical trends are still missing in many educational curricula which go for meeting a fundamental reform education focusing being a local and global citizenship, is fully obvious. This paper which was a historical review on what makes literacy was an attempt to provide a rather comprehensive review from its starting point to its status quo for those who are eager on rethinking knowledge epistemology and ontology for future directions in educational settings like Iranian. Through a historical review analysis, this paper was, indeed, an attempt to provide a critical appraisal review on literacy development theories, addressing some necessary future directions. Scholarship in New Literacy Studies focusing on some debates wedded in education in general and ELT in specific can contribute us to crystallize the paradigms occurred in literacy development and shed more light on new horizons in the macro level of theory and micro level of practices for all educational stakeholders in educational settings from educational policy makers to teachers and learners.

\section{References}

Banks, C. (2004). Diversity and citizenship education: Global perspectives. San Francisco: Jossey-Bass Barton.

Barton, D. H. (1999). Situated literacies: Reading and writing in context. London: Routledge.

Barton, D., Hamilton M., \& Ivanic, R. (1999). Situated literacies: Reading and writing in Context. London: Routledge.

Brice Heath, S., \& Street, B. (2008). On Ethnography in series Approaches to Language and Literacy Research National Conference on Research in Language and Literacy - Teachers College Columbia.

Cadiero-Kaplan, K. (2004). The Literacy curriculum and bilingual education. New York Peterlang.

Collins, J. (1995). Literacy and literacies. Annual Review of Anthropology, 24(4), 75-93. http://dx.doi.org/10.1146/annurev.an.24.100195.000451

Collins, J., \& Blot, R. (2003). Literacy and literacies: Texts power and identity. Cambridge. Cambridge University Press. http://dx.doi.org/10.1017/cbo9780511486661

Cope, B., \& Kalantzis, M. (2000). Multiliteracies: Literacy learning and the design of social futures. London: Routledge.

Cope, B., \& Kalantzis, M. (2009). Multiliteracies: New literacies, new learning. Pedagogies: An International Journal, University of Illinois Urbana-Champaign: Rutledge.

Ellis, V., Street, B., \& Fox, C. (2007). Rethinking English In Schools Continuum Books.

Fecho, B. (2000). Critical inquiries into language in an urban classroom. Research in the Teaching of English, 34(3), 359-393. 


\section{I Macrothink}

Global Journal of Educational Studies ISSN 2377-3936 2016, Vol. 2, No. 2

Fransman, J. (2006). Understanding literacy: A concept paper. Background Paper for the Education for all Global Monitoring Report: Literacy for Life, 13(4), 230-247

Furnis, G. (2004). Orality: The power of spoken word. New York: Palgrave Macmillan. http://dx.doi.org/10.1057/9780230510111

Gee, J. (1999). The New Literacy Studies: From "socially-situated" to "the work of the social". In D. Barton, M. Hamilton, \& R. Ivanic (Eds.), Situated literacies: Reading and writing in context. London: Routledge.

Graff, H. (2003). Understanding literacy in historical contexts: Past approaches and work in progress. Interchange, 34(4), 2-20.

Kress, G. (2000a). Multimodality. In B. Cope \& M. Kalantzis (Eds.), Multiliteracies: Literacy learning and the design of social futures (pp. 182-202). Melbourne: Macmillan.

Kress, G. (2000b). Multimodality: Challenges to thinking about language. TESOL Quarterly, 34(3), 337-340. http://dx.doi.org/10.2307/3587959

Lankshear, C., \& Knobel, M. (2011). New literacies. McGraw-Hill Education (UK).

Leung, C., \& Street, B. (Eds.) (2012). English - a Changing Medium for Education. Bristol: Multilingual Matters.

Masny, D. (2005). Learning and creative processes: A post-structural perspective on language and multiple literacies. International Journal of Learning, 12(5), 149-156.

Masny, D., \& Cole, D. (2008). Applying a multiple literacies theory in Australian and Canadian contexts. In A. Simpson, Future directions in literacy: International conversations. Sydney: University of Sydney Press.

New London Group. (1996). A Pedagogy of Multiliteracies: Designing social futures. Harvard Educational Review, 66(1), 60-92. http://dx.doi.org/10.17763/haer.66.1.17370n67v22j160u

New London Group. (2000). A pedagogy of multiliteracies: Designing social futures. In Cope, B. \& Kalantzis, M. (Eds.), Multiliteracies: Literacy learning and the design of social futures (pp. 9-38). London: Routledge.

Street, B. (1984). Literacy in theory and practice. Cambridge: Cambridge University Press.

Street, B., \& Hornberger, N. H. (Eds) (2007). Encyclopedia of Language and Education. Literacy, 2. Springer. http://dx.doi.org/10.4324/9780203463994

Street, B., \& Lefstein, A. (2007). Literacy: An advanced resource book. English Language and Applied Linguistics Routledge: London. http://dx.doi.org/10.4324/9780203463994

Vavrus. (2002). Humanism: A human perspective in English language teaching. International Seminar on Humanistic Language and Literature Teaching (18th \& 19th February , 2011), The Anna University, Chennai.

Vermeer, A. (2001). Breadth and depth of vocabulary in relation to L1/L2 acquisition and 


\section{Macrothink}

Global Journal of Educational Studies ISSN 2377-3936 2016, Vol. 2, No. 2

frequency of input. Applied Psycholinguistics, 22(6), 217-234. http://dx.doi.org/10.1017/S0142716401002041

\section{Copyright Disclaimer}

Copyright for this article is retained by the author(s), with first publication rights granted to the journal.

This is an open-access article distributed under the terms and conditions of the Creative Commons Attribution license (http://creativecommons.org/licenses/by/3.0/). 